\title{
Management of Performance in Higher Education Institutions: The Application of the Balanced Scorecard (BSC)
}

\author{
Peter N. Kiriri
}

Associate Professor of Marketing, United States International University - Africa (USIU-A), P.0 Box 1463400800 Nairobi, Kenya

\section{Abstract}

Universities play a crucial role in the development of any nation. The success of Higher Education Institutions (HEIs) is the bedrock of the growth in human capacity required to support the growth of an economy. However, HEIs have been criticized for not playing their rightful role in national development. This has been partly attributed to not being able to manage their performance in view of the dynamic and turbulent environment they are operating in. Most HEIs have been caught up in the "business as usual" situation preferring doing things in the traditional ways as opposed to changing with the times. As a result their survival has been at risk especially from those HEIs who have adopted the "business un-usual" mentality. It is as a result of the challenges facing Kenyan HEIs that this paper proposes an adoption of the Balanced Scorecard as a management tool in HEIs. This paper provides a review of literature on the HEI environment globally and in Kenya, highlighting the challenges faced by Kenyan HEIs and proposes the use of the BSC to address the same. The BSC is a tool that helps mainstream the vision and mission of HEIs in their activities thus making the HEIs become strategy focused organizations. The BSC is a strategic planning and management system used to align business activities to the vision and strategy of the organization and to monitor organization performance against strategic goals. Finally, a sample BSC for HEIs in Kenya is proposed. It is felt that if HEIs focused on the issues proposed and measured their performance on the issues identified, their performance will be improved tremendously.

Keywords: Balanced Scorecard, Higher Education Institution (HEIs), Performance management, Kenyan Universities

\section{Introduction}

The demand for higher education has increased tremendously in the recent past locally in Kenya, regionally and internationally. The demand has also been met with an increasing requirement of quality delivery of education and learning outcomes. 
Radical changes have also been witnessed in HEI as a result of various changes in the macro environment including a decline of state funding on public universities, and an increase in the number of private HEIs. Due to these factors, various stakeholder groups have increased their expectations on the HEIs.

Since the 1990s, accountability in higher education has become a challenging issue for HEIs. Increasingly, institutions of higher learning have been required to provide performance indicators-empirical evidence of their value-to state, alumni, prospective student, and other external stakeholders (Stewart and Carpenter-Hubin, 2000).

Competition in the higher education sector has also been tremendously increasing especially from the non traditional sources including e-universities. As international competition in educational services has become more intense, many countries have invested in university education in an effort to maintain international competitiveness (Chen, Yang and Shiau, 2006). To adapt to the strong competition, there is an immediate requirement for states to improve the quality of their national university education (Chen and Ho, 2003). Performance management and evaluation have become the focus of discussion in recent years as a way to aid in the new competitive landscape (Storey, 2002).

To survive in the turbulent environment, HEIs have adopted strategic management practices. In specific more and more HEIs are developing long term strategic plans. However, most of them have also been faced by the challenge of implementing the strategic plans. Various reason could be attributed to this including a lack of shared vision; being unable to link individual faculty and staff performance to the strategic plan; the inability to link incentives to performance; inability to fully exploit technology by staff and faculty; failure to plan and measure the right things that drive value; inability to align processes to the plans in order to deliver strategic goals and; inability to empower and reward people for doing the right things.

To ensure academic excellence in a time of increasing competition in the higher education sector, a university must apply an appropriate performance measurement system that reflects and gives the opportunity to improve on its research and teaching quality, and on the quality of its facilities and staff. Such a performance measurement system should also incorporate the perspectives of all university stakeholders. The performance of a university must be evaluated via an appropriate method and the adoption of a robust performance measurement system that is key to improving the competitive status of a university, both locally and internationally, while at the same time maintaining its academic excellence (Chen, Wang and Yang, 2009).

To adapt to the great competition from all over the world, there is an important and immediate required improvement to the quality of higher education to meet international academic trend and raise overall academic standards and education quality (Chen, Wang and Yang, 2009). In response to growing concerns from 
stakeholders about poor or inconsistent quality, institutions of higher education are increasingly seeking ways to improve education quality (Lawrence and McCullough, 2001).

\section{State of HEIs in Kenya}

The Kenyan higher education sector is faced by a myriad of issues and challenges both emanating from internal sources as well as externally. Some of these issues face both the private and public universities. The issues range from financial stability to lack of consistent quality. For the public universities, since the mid 1980s government funding has declined in real terms. The causes have been many but generally have included changing donor priorities, changing government rules and regulations to cope with national economic turbulence, international economic trends, legislation and political trends in the country (Onyango, 1996). Numerous problems facing public universities in Kenya have resulted in a constant rise in unit costs of education, declining academic achievement, and the near collapse of physical facilities (Mutula, 2002).

Also afflicting Kenyan Universities are issues of gender inequality, and low research capacity, quality of graduates produced, ineffective adoption of the use of IT. The question of unemployment among graduates and the rush to enroll in universities abroad for courses offered locally at a cheaper cost is disturbing (Mutula, 2002). Both public and private universities are faced with a situation whereby much of their income goes towards operating expenses with very little or nothing left for research and infrastructure growth.

In the recent past the education sector in Kenya has witnessed massive expansion especially in terms of student's enrollments. The massive expansion of university education in Kenya has not taken place at the same pace as the infrastructure to meet the needs of the students (Bogonko, 1992). As universities have admitted more and more students every year, they did not build lecture halls, hostels, laboratories, workshops and hostels at the same pace. The lecturers in public universities have to deal with large classes, without the relevant communication media to handle such numbers (Mutula, 2002). These lecturers are a minimal 4,000 to cater for about 60,000 students. The ratio of staff to students is about 1:60 or more in some undergraduate programmes and 1:15 or 20 for masters' programmes and 1:8 PhD students (Aduol, 2001).

As a result of the above, a decline in education standards have been noted (Mutula, 2002). The declining standards in local universities have created perfect conditions for foreign universities to do lucrative business in education (Kigotho, 2001).

As mentioned earlier, financials have been an issue in the local universities. The public universities are trying to put in place measures to generate income to augment declining government allocation. 
In a study conducted by Mwiria et. al., (2006) on university education in Kenya, a number of challenges were identified that required immediate and continued action. These included:

Need for improving student welfare;

Quality control and internal/external evaluation systems;

Enhancing equity by recruiting more students and staff from traditionally disadvantaged groups/regions and providing facilities for physically challenged students;

Improving internal governance systems;

Increasing research funding;

Procurement of modern teaching and learning equipment, textbooks and journals;

Electronic linkage to other institutions and resources outside Kenya;

Training and upgrading the skills of reform managers and academics;

Supporting staff participation in local and international academic and non-academic gatherings;

Strengthening linkages between the public universities themselves and between public and private institutions by promoting collaboration in training and research;

Strengthening regional and international linkages by funding collaborative teaching and research programmes and student and staff exchanges;

Diversification of revenue bases/sources to ensure financial stability and sustainability;

Offering attractive market driven on demand programmes at affordable costs

Dissemination of research findings;

Innovative strategies of widening access to university education; and

Instituting of monitoring and evaluation systems to various facets of education effectiveness.

In considering the performance of both public and private universities, it is imperative to consider the aims of university education in Kenya as outlined by the Ministry of Education, (1994):

To develop, advance, preserve and disseminate knowledge and to stimulate intellectual life.

To train and prepare high level manpower needed for development.

To promote cultural development and the highest ideas and valves of the society. 
To provide through research and consulting knowledge, skills and services to the community.

To assist the government in achieving its planned development.

It is a result of reviewing the performance of universities in achievement of the broad aims stated above that leads to a conclusion of shortfalls on the expected broad outcomes. This has begging questions as to what is ailing the Kenyan university and whether the reforms undertaken so far in the Kenyan Education sector are working as expected or not. This paper proposes the use of strategy management and deployment tools to ensure that universities in Kenya are playing their rightful role in national and economic development. The trend all over the world is for increased accountability for universities and their employees on their performance. The Balanced Scorecard has been tried and tested by various HEIs and hailed as one tool that if well implemented in HEIs would ensure fulfillment of the missions and visions of such institutions.

There is a need for educational institutions in Kenya to establish a set of performance management tools to establish educational objectives and standards, and to increase the competitiveness of university education in a globalised environment. These are the pressing imperatives for university education today (Chen, Yang and Shiau, 2006).

\section{The Balanced Scorecard (BSC)}

In 1992, Robert S. Kaplan and David P. Norton introduced the balanced scorecard, a set of measures that allow for a holistic, integrated view of business performance. The scorecard was originally created to supplement "traditional financial measures with criteria that measured performance from three additional perspectives-those of customers, internal business processes, and learning and growth" (Kaplan and Norton, 1996). The BSC, measures performance and successful strategy implementation and has been implemented in hundreds of companies and organizations with generally successful results (Dumond, 1994; Kaplan and Norton, 2001),

The Balanced Scorecard was developed in response to concerns about traditional methods of measuring organizational success, which were felt to be too focused on financial measures, and hence backwards looking. Kaplan and Norton's Balanced Scorecard consists of a series of performance measures combining both financial and non-financial metrics, grouped under four perspectives.

The reason for use of the balanced scorecard is to formulate strategy objectively in the four perspectives, considering their multidimensional effect (Epstein and Roy, 2004). The balanced scorecard tracks key strategic elements through a balanced series of performance indicators to ensure that action is meeting strategic objectives, while demonstrating that the institution is meeting accountability expectations and legislative requirements. 
By adopting financial and non-financial measures and measuring current performance outcomes as well as future performance drivers, the BSC gives feedback around both the internal business processes and external outcomes in order to continuously improve strategic performance. To this end, the BSC employs four perspectives and develops metrics, collects and analyzes data relative to each of the four perspectives (Papenhausen and Einstein, 2006; Bailey et al., 1999).

The financial perspective - "To succeed financially, how should we appear to our stakeholders?" - uses traditional financial measures to measure past performance.

The customer (stakeholder) perspective - "To achieve our vision, how should we appear to our customers?" (How do stakeholders see us?) - focuses on stakeholder satisfaction and the value propositions for each stakeholder. Relevant stakeholders for an academic institution include faculty, staff, administration, students, parents, alumni, employers, the community, and the image of the institution.

The internal process perspective - "To achieve our vision, how will sustain our ability to change and improve?" (At what must we excel?) - refers to internal organizational processes. Metrics based on this perspective allow managers to gauge how well their organization is running, and whether its products and services conform to customer requirements (the mission). This also translates to quality of educational offering and providers.

The learning and growth perspective - (can we improve our ability to grow?) includes intangible assets such as employee knowledge and organizational cultural attitudes for both individual and organizational self-improvement. In a knowledgeworker organization, people - the repository of knowledge - are the main resource. This translates to the currency of the program, and providers. The program must be leading, to attract employees, as well as to sustain the institution

The BSC is a strategic planning and management system used to align business activities to the vision and strategy of the organization and to monitor organization performance against strategic goals. The BSC has evolved from its early use to a full strategic planning and management system (Kaplan and Norton, 1996). The balanced scorecard system emphasizes articulation of strategic targets in support of goals. In addition, measurement systems are developed to provide data necessary to know when targets are being achieved or when performance is out of balance or being negatively affected.

Originally meant for the commercial (for profit) organizations, the BSC has been adopted by nonprofit organizations both public and non-public. However in the process of adoption, different perspectives have been recommended for different organizations. Some of the changes adopted include the naming of the four perspectives and including of extra perspectives that addresses the mission of an organization. Various model of BSC have been recommended for HEI by various authors as captured in a section below. 


\section{Reasons Why HEIs Should Adopt the BSC}

The concept of applying the Balanced Scorecard to a university is increasingly popular among researchers. There are many studies related to this concept, including the uses of the Balanced Scorecard for university management (Stewart and Carpenter-Hubin, 2000; Lawrence and Sharma, 2002; Ruben, 1999), for academic departments (Haddad, 1999; Bailey et al., 1999; Chang and Chow, 1999), for university research (Pursglove and Simpson, 2000), for university teaching (Southern, 2002), and for internal service providers in a university (Purslove, 2002). Not only is the concept of the Balanced Scorecard widely praised among academic researchers, but it is also being increasingly applied in universities. There are reports of colleges using the balanced scorecard to develop frameworks for measuring institutional effectiveness on the macro level (Karathanos and Karathanos, 2005; Ruben, 1999). Such adaptations provide university administrators with a measurement system that is not only linked to mission and strategy, but is also a learning model that supports continuous improvement and environmental responsiveness.

In view of the fact that HEIs are now facing severe competition and that there is a need to reform their operations, universities need to develop strategic management tools if they are to turn strategy into action (Chen, Yang and Shiau, 2006). Adopting the key performance indicators of instruments such as BSC would allow universities to develop and allocate resources in a strategically coherent manner. In turn, this can be translated into effective reorganization of such operational matters as daily staff tasks (Kaplan and Norton, 2001a).

Universities must also remain competitive to meet the demands of accrediting bodies. Administrators face increasing demands for quality and accountability from internal and external forces and constituents, and in the past have looked to the business management literature for help in developing programs that keep pace with the demands of a competitive environment (Welsh and Metcalf, 2003).

The balanced scorecard framework is recommended because it enables the formulation of strategies that focus on continuous improvement efforts that are linked to vision and mission and it points to critical activities and objectives, and suggests ways of measuring them and presenting the results in a concise and organized fashion (McDevitt et. al., 2008).

The BSC has been identified to help HEIs in (D'Uggento, Iaquinta and Ricci, 2008):

Translating vision into actions;

Communicating and linking strategic objectives and measures;

Linking unit goals to macro goals in all scorecard areas, developing strategies to achieve them and allocating resources to different strategies;

Developing reliable measures of progress toward goals; 
Feedback and learning.

The adoption of BSC by HEIs help create a cause-and-effect linkage involving feedback from staff and faculty members and communication among corresponding functions (Chen, Yang and Shiau, 2006). The BSC represents an opportunity to improve strategy through staff involvement, to create a multidimensional control system of performance and to leave behind the traditional bureaucratic managerial model in most universities and adopting a modern one. BSC has the advantage to grant an integrated approach to the several variables regarding Academia, being particularly useful in the big and complex Universities. Also the BSC ensures HEIs appreciate the concept of Accountability both at internal and external level considering social and environmental factors (Chen, et. al., 2006).

Introduction of the BSC in an educational institution requires faculty staff to work together. It begins with senior supervisors who are responsible for policy making and execution in a top-to-bottom hierarchy. Five basic principles are involved in the establishment of the BSC as part of the strategic core of an organization (Kaplan and Norton, 2001):

Translating the strategy to operational terms.

Aligning the organization to the strategy.

Making the strategy part of everyone everyday job.

Making strategy a continuous process.

Mobilizing change through leadership.

\section{Performance Measurement}

According to Osborne and Gaebler (1992), organizations need to measure performance using objective methods. They contend that if one does not measure results, they cannot tell success from failure; If they cannot see success, they cannot reward it; If they cannot reward success, they are probably rewarding failure; If they cannot see success, they cannot learn from it; If they cannot recognize failure, they cannot correct it; If they can demonstrate results, they can win public support.

With important stakes such as increasing financial resources, encouraging highquality student applicants, and attracting faculty dependent upon how they "measure up," universities are rightly concerned with how best to present themselves. Institutions attempt to improve accountability while dealing with the more difficult and complex issue of how to improve university effectiveness. The real test for institutions is to create meaningful systems for strategic organizational assessment and then use that information in internal policy and resource allocation decisions (Stewart and Carpenter-Hubin, 2000).

The Balanced Scorecard translates an organization's mission and strategy into a comprehensive set of performance measures that provides a framework for a 
strategic measurement and management system. Organizations that adopt this approach achieve the following (Kaplan and Norton, 1996):

Clarify and gain consensus about vision and strategic direction.

Communicate and link strategic objectives and measures throughout the organization.

Align departmental and personal goals to the organization's vision and strategy.

Plan, set targets, and align strategic initiatives.

Conduct periodic and systematic strategic reviews.

Obtain feedback to learn about and improve strategy.

Unlike performance measurement approaches that focus on controlling behaviour, the balanced scorecard affords opportunities to motivate organizational members to achieve goals that support long-term vision. Through new and expanded applications, the scorecard can play a central role in integrating strategic management systems by linking long-term strategic objectives with short-term actions (Kaplan and Norton, 1996).

\section{SUGGESTED HEI PERFROMANCE PERSPECTIVE MEASURES}

Having reviewed the issues facing HEIs in Kenya, and the critical role the BSC can play in ensuring that the HEIs are performing to their call, the author proposes some areas of performance measurement that could be adopted. The BSC is built on translating strategy into actions and as such the recommendations herein are seen to be in line with the objectives and strategies of most of the HEIs. By aligning the performance of all the members of an institution to such a framework it makes strategy become everyone's everyday job and as such all are able to contribute to the achievement $\mathrm{f}$ the performance goals of a HEI.

\begin{tabular}{|l|l|}
\hline Objective & Measure / indicator \\
\hline Financial Perspective & \\
\hline $\begin{array}{l}\text { Increased revenue generation } \\
\text { from tuition }\end{array}$ & $\begin{array}{l}\% \text { increase in tuition revenues } \\
\% \text { increase in other revenues }\end{array}$ \\
\hline Reduction of wastage & $\begin{array}{l}\% \text { reduction in wastages } \\
\% \text { reduction in repeat jobs }\end{array}$ \\
\hline Reduction of operating costs & $\begin{array}{l}\% \text { reduction in operating expenses } \\
\text { Expense - income ratio }\end{array}$ \\
\hline Increased research funding & $\%$ increase in research funds \\
\hline Increase in consulting revenues & Amount of consulting revenues \\
\hline Reduction in maintenance costs & $\%$ reduction in maintenance costs \\
\hline Increased fundraising Kitty & Total increase in Funding \\
\hline
\end{tabular}




\begin{tabular}{|l|l|}
\hline $\begin{array}{l}\text { Revenues from commercialized } \\
\text { research }\end{array}$ & \% increase in research revenues \\
\hline $\begin{array}{l}\text { Revenues from industry } \\
\text { collaborations }\end{array}$ & \% increase in revenues from collaborations \\
\hline Revenue diversification & Revenue Mix \\
\hline
\end{tabular}

\begin{tabular}{|l|l|}
\hline Objective & Measure / indicator \\
\hline $\begin{array}{l}\text { Customer/Stakeholder } \\
\text { Perspective }\end{array}$ & \\
\hline Increased student satisfaction & Customer satisfaction index \\
\hline Employers Satisfaction & Employers satisfaction index \\
\hline Alumni Satisfaction levels & Alumni satisfaction index \\
\hline Increased in Number of students & Number of students \\
\hline Parents/Guardians' Satisfaction & Parents satisfaction index \\
\hline Graduate employment rate & \% of graduates employed within one year \\
\hline $\begin{array}{l}\text { Student completion within the } \\
\text { planned time }\end{array}$ & $\begin{array}{l}\text { \% of graduates completing their course of } \\
\text { study within the allotted time }\end{array}$ \\
\hline $\begin{array}{l}\text { Increase in 1stass Honours } \\
\text { students }\end{array}$ & \% of graduate receiving first-class honors' \\
\hline $\begin{array}{l}\text { Increased enrollment of } \\
\text { undergraduates in Masters } \\
\text { Programs }\end{array}$ & $\begin{array}{l}\text { \% of graduates going for further study within } \\
\text { one year }\end{array}$ \\
\hline Increased Student retention & Retention rate \\
\hline Enhanced Public Image & $\begin{array}{l}\text { Among the top 3 } \\
\text { Number of sustainable CSR projects }\end{array}$ \\
\hline Increased level of collaborations & $\begin{array}{l}\text { Number of local collaborations } \\
\text { Number of international collaborations } \\
\text { Number of staff and students on exchange } \\
\text { programs }\end{array}$ \\
\hline Involvement of alumni & $\begin{array}{l}\text { Number and value of projects supported by } \\
\text { alumni }\end{array}$ \\
\hline
\end{tabular}

\begin{tabular}{|l|l|}
\hline Objective & Measure / indicator \\
\hline $\begin{array}{l}\text { Internal Business Processes } \\
\text { Perspective }\end{array}$ & \\
\hline Facility utilization & Number of contact hours per course \\
\hline Student to Lecturer ratio & Lecturer-student ratio \\
\hline $\begin{array}{l}\text { Integrated use of technology in } \\
\text { Teaching }\end{array}$ & $\begin{array}{l}\text { Number of courses taught using technology } \\
\text { support }\end{array}$ \\
\hline
\end{tabular}




\begin{tabular}{|l|l|}
\hline Student to computer ratio & $\begin{array}{l}\text { Number of computers per full time student } \\
\text { equivalent }\end{array}$ \\
\hline Use of internet in learning & $\begin{array}{l}\text { Number of computer network connections } \\
\text { Number of e-learning supported courses } \\
\text { Internet usage rate }\end{array}$ \\
\hline Academic staff Quality & $\begin{array}{l}\text { \% of lecturers holding doctoral degree or } \\
\text { equivalent }\end{array}$ \\
\hline Teaching effectiveness & $\begin{array}{l}\text { Student opinions on lecturer teaching } \\
\text { efficiency }\end{array}$ \\
\hline Teaching excellence & $\begin{array}{l}\text { Number of national and international awards } \\
\text { related to the learning process }\end{array}$ \\
\hline $\begin{array}{l}\text { Quality of research and library } \\
\text { support }\end{array}$ & $\begin{array}{l}\text { Number of online databases subscribed to } \\
\text { Number of journals subscribed to } \\
\text { Number of hours of library and computer } \\
\text { service }\end{array}$ \\
\hline Quality of library services & $\begin{array}{l}\text { Number of books on shelf - \% library stock } \\
\text { issued } \\
\text { Age of books on shelf } \\
\text { Level of satisfaction with library services } \\
\text { Annual Library Budget }\end{array}$ \\
\hline Reduced Turnaround time & $\begin{array}{l}\text { \% reduction in turnaround time of university } \\
\text { processes }\end{array}$ \\
\hline Automation of processes & $\begin{array}{l}\text { \% automated processes } \\
\text { Computer usage rate } \\
\text { Budgeted vote on ICT }\end{array}$ \\
\hline Use of ICT & $\begin{array}{l}\text { Number of new demand driven programs } \\
\text { Number of students enrolled in new } \\
\text { programs } \\
\text { Revenues from new programs }\end{array}$ \\
\hline Market Driven Programs & $\begin{array}{l}\text { Number of courses taught using innovative } \\
\text { techniques }\end{array}$ \\
\hline Increased Distribution/Reach & $\begin{array}{l}\text { Student Mix (International vs Local; Student } \\
\text { Diversity; disadvantaged Students) } \\
\text { Distance learning students }\end{array}$ \\
\hline $\begin{array}{l}\text { Number of units passing an external quality } \\
\text { assurance assessment } \\
\text { Faculty Assessment }\end{array}$ \\
$\begin{array}{l}\text { Rating by CHE } \\
\text { Reviews by external program auditors }\end{array}$ \\
\hline ICT Capacity utilization levels \\
\hline Mrogram
\end{tabular}




\begin{tabular}{|l|l|}
\hline Objective & Measure / indicator \\
\hline $\begin{array}{l}\text { Learning and Growth } \\
\text { Perspective }\end{array}$ & $\begin{array}{l}\text { Number of staff development events attended } \\
\text { per FT member of staff } \\
\text { Percentage of new appointments at lecturer, } \\
\text { senior lecturer/ and professor level }\end{array}$ \\
\hline Staff and Faculty development & $\begin{array}{l}\text { Number of staff/faculty registered in PhD } \\
\text { Programs } \\
\text { Number of staff-training hours }\end{array}$ \\
\hline Individual development & $\begin{array}{l}\text { Number of journal publications } \\
\text { Number of conference presentations }\end{array}$ \\
\hline Research output & Leadership index \\
\hline Leadership development & Staff/Faculty satisfaction index \\
\hline Staff/Faculty satisfaction & $\begin{array}{l}\text { Successful Research grant applications } \\
\text { submitted per annum per member of academic } \\
\text { staff }\end{array}$ \\
\hline $\begin{array}{l}\text { Faculty involvement in seeking } \\
\text { research grants }\end{array}$ & $\begin{array}{l}\text { Number of staff on fixed term contracts as \% of } \\
\text { all staff employed }\end{array}$ \\
\hline $\begin{array}{l}\text { Increased in FT faculty } \\
\text { members }\end{array}$ & $\begin{array}{l}\text { Staff/Faculty retention rate } \\
\text { Ratio of FT to PT faculty }\end{array}$ \\
\hline $\begin{array}{l}\text { Recruitment and retention of } \\
\text { competent staff/faculty }\end{array}$ & Number of student disturbances/riots reported \\
\hline Leadership quality &
\end{tabular}

\section{Conclusion}

Although the BSC has been implemented in developed countries such as European and American countries for many years, it has not until recently been adopted by organizations in Kenya. However, the BSC has rarely been applied in higher education sectors in Kenya. The discussion in this paper authenticated that BSC is a performance management system and a strategic management tool that can and should be adopted by HEIs considering the environment they are operating in.

\section{References}

[1] Aduol, F. W. O. (2001). "Financing Public Universities in Kenya. A Model Based on Ratonalised Student Unit Costs and staffing." In Higher Education in Africa. Issues in Management and Leadership Nairobi: Kenyatta University

[2] Bailey, R.A., Chow, C.E. \& Haddad, K. (1999). "Continuous improvement in business education: insights from the profit-sector and business school Deans", Journal of Education for Business, Vol. 74 No. 3, pp. 165-80.

[3] Bogonko, S.N. (1992). A History of Modern Education in Kenya (1985-1991) Nairobi: Evans Brothers Ltd. 
[4] Chen,S-H, Wang,H. H \& Yang, K. J (2009). Establishment and application of performance measure indicators for universities" The TQM Magazine, Vol. 21, No.3, pp.220-235

[5] Chen Shun-Hsing \& Yang Ching-Cho \& Shiau Juin-Yan (2006). "Scorecard in the performance evaluation of higher education",The TQM Magazine, Vol. 18, No.2, pp.190-205.

[6] Chang, O.H. \& Chow, C.W. (1999). "The balanced scorecard: a potential tool for supporting change and continuous improvement in accounting education", Issues in Accounting Education, Vol. 14, No. 3, pp. 395-412.

[7] Chen, P.C., \& Ho, C.Y. (2003). "US university academy reputation ranking indicators research: example of US news and world report", Education Research Monthly Magazine, Vol. 116 pp.77-96.

[8] Davies, B. \& Ellison, L. (1998). Futures and strategic perspectives in school planning, international Journal of Educational Management, 12(3), 133- 140.

[9] Dúggento, A. M, Iaquinta, M \& Ricci, V.(2008). 'A New Approach in University Evaluation: The Balanced Scorecard".

[10] Epstein, M.J. \& Roy, M. (2004). "How does your board rate?" Strategic Finance, February, pp. 25-31.

[11] Haddad, K.M. (1999). "Using the balanced scorecard for improving finance education", Financial Practice \& Education Vol. 9, No. 1, pp. 92-101.

[12] Kaplan, R.S. \& Norton, D.P. (1992). "The balanced scorecard - measures that drive performance", Harvard Business Review, January-February, pp. 71-9.

[13] Kaplan, R.S. \& Norton, D.P. (1993). "Putting the balanced scorecard to work", Harvard Business Review, September-October, pp. 134-42.

[14] Kaplan, R.S. and\& Norton, D.P. (1996a). "Using the balanced scorecard as a strategic management system", Harvard Business Review, January-February, pp. 75-85.

[15] Kaplan, R.S. \& Norton, D.P. (1996b). "Strategic learning and the balanced scorecard", Strategy \& Leadership, September-October, pp. 18-24.

[16] Kaplan, R.S. \& Norton, D.P. (2001). "Transforming the balanced scorecard from performance measurement to strategic management: part I", Accounting Horizons, Vol. 15 No. 1,pp. 87-104.

[17] Kaplan, R.S. \& Norton, D.P. (1996). "The Balanced Scorecard - Translating Strategy into Action", Harvard Business School Press, Boston, USA.

[18] Kaplan, R.S. \& Norton, D.P. (2004). "How strategy maps frame an organization's objectives", Financial Executive, March/April, pp. 40-5.

[19] Kaplan, R.S. \& Norton, D.P. (2001a). The Strategy-Focused Organization: How Balanced Scorecard Companies Thrive in the New Business Environment, Harvard Business School Press, Boston, MA.

[20] Karathanos, D. \& Karathanos, P. (2005). "Applying the balanced scorecard to education”, Journal of Education for Business, Vol. 80 No. 4, pp. 222-30. 
[21] Kriemadis, A. (1997). Strateplanning in higher education athletic departments, International Journal of Educational Managic gement, 11(6), 238- 247.

[22] Kigotho, W. (2001). "The high cost of varsity education in Britain", East Africa Standard, .

[23] Kigotho, W. (2001), "Inquiry blames poor living conditions for riots", Times Higher Education Supplement, No.1469, pp.9.

[24] Lawrence, S. \& Sharma, U. (2002). "Commodification of Education and Academic Labour - Using the Balanced Scorecard in a University Setting", Critical Perspective on Accounting, Vol. 13, pp. 661-677.

[25] Lawrence, J.J. \& McCullough, M.A. (2001). "A conceptual framework for guaranteeing higher education", Quality Assurance in Education, Vol. 9 No. 3, pp. 139-52.

[26] McDevitt, R, Giapponi, C \& Solomon, N. (2008). "Strategy revitalization in academe: a balanced scorecard approach".

[27] Ministry of Education (1994). Information Handbook. Nairobi: Jomo Kenyatta Foundation

[28] Mutula, S.M. (2002). University education in Kenya: current developments and future outlook. MCB UP Ltd, Gaborone, Botswana.

[29] Mwiria, K, Ngéthe, N, Ngome, C, Ouma-Odero, D, Wawire, V \& Wesonga,D (2006). Public \& Private Universities in Kenya: New Challenges, Issues \& Achievements, James Currey Ltd, Oxford OX2 0BS, UK.

[30] O'Neil, H.F. Jr, Besimon, E.M., Diamond, M.A. \& Moore, M.R. (1999). “Designing and implementing an academic scorecard", Change, Vol. 31 No. 6, pp. 32-40.

[31] Onyango, R. (1996). "Strategic planning and implementation for higher education libraries, strategic management for higher education librarians", Gaborone, DSE/UB-DLIS Training Course, pp.45-82.

[32] Pursglove, J. \& Simpson, M. (2000). "A Balanced Scorecard for University Research", Proceedings, 2nd International Conference on Performance Measurement, Cambridge, UK, pp 467-474.

[33] Pursglove, J. (2002). "A case study in building a Balanced Scorecard for an internal service provider", Proceedings, 3rd International Conference on Performance Measurement and Management, Boston, USA, pp 767-772

[34] Papenhausen C. \& Einstein W. (2006. Insights from the Balanced Scorecard Implementing the Balanced Scorecard at a college of business", Measuring Business Excellence, Vol.10, NO.3, pp.15-22.

[35] Ruben, B. D. (1999). "Toward a Balanced Scorecard for Higher Education: Rethinking the College and University Excellence Indicators Framework", the Hunter Group White Paper Series, October.

[36] Southern, G. (2002). "From Teaching to Practice, via Consultancy, and then to Research?" European Management Journal, Vol. 20, No. 4, pp 401-406. 
[37] Stewart, A.C. \& Carpenter-Hubin, J. (2000). "The Balanced Scorecard beyond Reports and Rankings", Planning for Higher Education Vol. 29, No. 2, pp 3742.

[38] Storey, A. (2002). "Performance management in schools: could balanced scorecard help?" School Leadership and Management, Vol. 22 No.3, pp.32138. 